\title{
Study on Compression Surface Deformation of Waveriders
}

\author{
Kai Cui ${ }^{1}$, Yingzhou Xu ${ }^{2}$, Li Guang-li ${ }^{3}$, Yao Xiao ${ }^{4}$ \\ State Key Lab of High-temperature Gas Dynamics, Institute of Mechanics, Chinese Academy of Sciences, Beijing, \\ 100190, China \\ School of Engineering Science, University of Chinese Academy of Sciences, Beijing, 100049, China
}

\begin{abstract}
A novel design method that is based on a local shape deformation technique is presented in this paper to extend the design space of waveriders. Moreover, an inviscid analysis based optimization study was carried out to research the effect of compression surface deformation on aerodynamic performances of waveriders by integrating the increment-based parameterization method, the computational fluid dynamic analysis, and the differential evolution algorithm. Afterwards, six selected waverider configurations were polished to blunt leading edges, and then their aerodynamic performances were evaluated by solving the Navier-Stokes equations. The results show that both the L/D and the relative pressure center coefficient of the waverider produce significant changes with the variation of compression surface shape.
\end{abstract}

\section{Nomenclature}

$\begin{array}{ll}M a & =\text { Mach number } \\ C_{l} & =\text { lift coefficient } \\ C_{d} & =\text { drag coefficient } \\ L / D, K & =\text { lift-to-drag ratio (aerodynamic efficiency) } \\ X c p & =\text { center of pressure } \\ i, j & =\text { grid point index } \\ \mathbf{r}^{i, j} & =\text { coordinate vector of a grid point } \\ \Delta \mathbf{r}^{i, j} & =\text { increment vector } \\ A x & =\text { increment amplitude in the } x \text { direction } \\ A y & =\text { increment amplitude in the } y \text { direction } \\ A z & =\text { increment amplitude in the } z \text { direction } \\ H & =\text { Altitude } \\ \alpha & =\text { angle of attack } \\ \lambda & =\text { penalty parameter } \\ C_{x} & =\text { control function in the } x \text { direction } \\ C_{y} & =\text { control function in the } x \text { direction } \\ C_{z} & =\text { control function in the } x \text { direction }\end{array}$

\section{Introduction}

$\mathrm{T}$ HE pursuit of hypersonic vehicles has been underway for decades. Blended wing bodies, lifting bodies, bodies of revolution and waverider are four typical hypersonic aircraft configurations [1]. Among these four classes, the waverider [2-4] is a unique configuration. When flying at a specified design condition (specific Mach number and angle of attack), a waverider has an attached shock wave along its leading edge and looks like being riding on top of the shock wave, hence the term "waverider". The high pressure behind the shock wave under the waverider does not leak around the leading edge to the top surface, the flow field over the bottom surface is contained, and the high pressure is preserved. Because of this advantage, waveriders can exhibit high lift-to-drag ratios (L/D).

\footnotetext{
${ }^{1}$ Associate Professor, State Key Lab of High-temperature Gas Dynamics, kcui@imech.ac.cn.

${ }^{2}$ Graduate student, State Key Lab of High-temperature Gas Dynamics, xuyingzhou@imech.ac.cn

${ }^{3}$ Graduate student, State Key Lab of High-temperature Gas Dynamics, xiaoyao@imech.ac.cn.

${ }^{4}$ Graduate student, State Key Lab of High-temperature Gas Dynamics, liguangli@imech.ac.cn.
} 
Waveriders are promising and tailored for hypersonic vehicle configurations. In recent years, interest in hypersonic flight has grown explosively and research of waveriders has been a heated activity.

Design method of waverides derived from different flow fields is one of the major research topics. The early work was around some simple generating flow fields such as axisymmetric flow fields, inclined circular cone flow fields, elliptic cone flow fields [6-8] and wedge cone flow fields [9]. In recent years, waveriders are also created from more complex flow fields such as general conical flow fields [10, 11], pointed von Karman ogive flow fields [12] and multistage compression cone flow fields [13]. These work improved the performance of waveriders. New hypersonic vehicle concepts based on waveriders have grown explosively [14-20].

Since 1960's, optimization of waverider configurations has been one of the main research topics of waveriders. In 1987, Kevin Bowcutt [21] started from conical flow fields and developed a new class of configurations named "viscous optimized waveriders". In the evaluation, he calculated viscous friction forces with reference temperature method and performed optimization on leading edge using a numerical non-linear simplex algorithm [3]. In 1998, Corda [22] derived waveriders from axisymmetric flow fields generated by power-law bodies and reinforced Bowcutt's findings. Thereafter many studies were conducted on waveriders with a combination of different creating approaches and optimization methods [14-15, 23-27].

Waverders are defined by generating flow fields and leading edge profile on the shock wave surface. Most work of optimization were focused on the leading edge by changing profile of leading edge on the shock wave surface in a given flow field. However, there were few studies on optimization of the lower surface of waverider (compression surface). Since the lower surface is on the windward side, changings of the lower surface would significantly affect the waverider's aerodynamic performance [28, 29].

In the present work, our major purpose is to research the effect of compression surface deformation on aerodynamic performances of waveriders. A novel design method of waveriders which is based on a local shape deformation technique is presented first. Then an inviscid analysis based optimization study was carried out to research the effect of compression surface deformation on aerodynamic performances of waveriders by integrating the increment-based parameterization method, the computational fluid dynamic analysis, and the differential evolution algorithm. Afterwards, six selected waverider configurations were polished to blunt leading edges, and then their aerodynamic performances were evaluated by solving the Navier-Stokes equations.

\section{Waverider Design Method Based on Local Shape Deformation}

Waveriders are normally designed for hypersonic flight regime. In this condition, disturbances in the flow field can only propagate downstream. Hence disturbances created at points behind the shock wave are limited to be felt inside the shock wave cone. Based on this fact, we give finite deformations to the middle rear part of an existing waverider's compression surface. The deformation area and magnitude are appropriately controlled to keep the wavrider's characteristics, i.e. to keep the shock wave along the leading edge and make sure the high pressure behind the shock wave under the waverider does not leak. Using this approach, a new series of waveriders are easily derived from an original waverider.

In order to parameterize the deformation, an increment-based method is used [5]. The shape of the compression surface is defined by grid points. Deformation of the surface is described by following equation:

$$
\left\{\begin{array}{l}
\mathbf{r}^{i, j}=\mathbf{r}_{0}^{i, j}+\Delta \mathbf{r}^{i, j} \\
\Delta \mathbf{r}^{i, j}=A_{x} C_{x}(\mathbf{p})^{i, j} \mathbf{x}+A_{y} C_{y}(\mathbf{p})^{i, j} \mathbf{y}+A_{z} C_{z}(\mathbf{p})^{i, j} \mathbf{z}
\end{array}\right.
$$

where, $i$ and $j$ are indexes of the grid points, $\boldsymbol{r}_{0}{ }^{i, j}$ is the coordinate vector of a grid point which defines the original compression surface. $\Delta \boldsymbol{r}^{i, j}$ is the increment vector which defines the displacement of the point. $A_{x}, A_{y}$ and $A_{z}$ are the increment amplitude. $C_{x}, C_{y}$ and $C_{z}$ are control functions in three direction. $\boldsymbol{P}$ is the set of parameters in three direction which is used as design variable in the optimization process. Fig.1 shows an example of the deformation. 


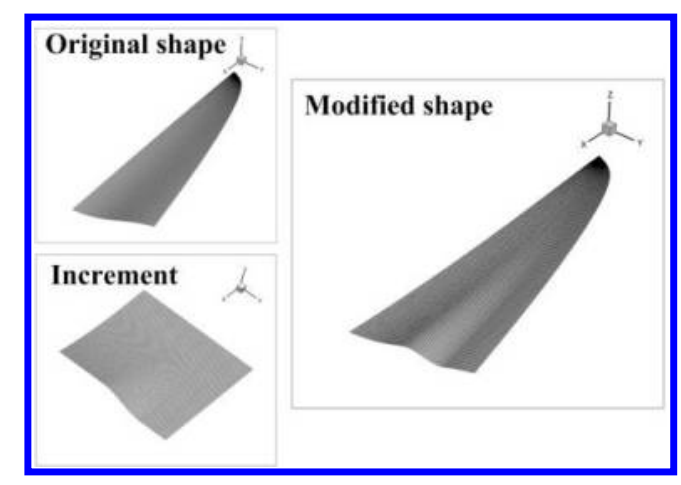

Figure 1. An example of shape parameterization

In the present work, parameterization is focused on two profile edges of the compression surface, the symmetry edge in $X$ direction and the rear edge in $Y$ direction. The leading edge is not changed. The control function of the symmetry edge is described by following equation:

$$
y=\left\{\begin{array}{l}
0, \quad x \in\left[0, P_{1}\right] \\
\left(\frac{x-P_{1}}{1-P_{1}}\right)^{2}, \quad x \in\left[P_{1}, 1\right]
\end{array}\right.
$$

The control function of the rear edge is described by following equation:

$$
y=\left\{\begin{array}{l}
1, \quad x \in\left[0, P_{2}\right] \\
\frac{1}{2} *\left[1+\cos \left(\frac{x-P_{2}}{P_{3}-P_{2}} \bullet \pi\right)\right], \quad x \in\left[P_{2}, P_{3}\right] \\
0, \quad x \in\left[P_{3}, 1\right]
\end{array}\right.
$$

In equation (2) and (3), $P_{1}, P_{2}$ and $P_{3}$ are the intersection points of the lines and the curves which define the shape of the edges. Using this method, if $P_{1}, P_{2}$ and $P_{3}$ are elaborately designed, the deformation zone can be far away from leading edge, hence there is no deformation in the specific area of waverider's lower surface near leading edge. Therefore wavrider's characteristics can be kept.

\section{Optimization of Compression Surfaces}

An inviscid analysis based optimization study was carried out to research the effect of compression surface deformation on aerodynamic performances of waveriders by integrating the increment-based parameterization method, the computational fluid dynamic analysis, and the differential evolution algorithm. All computations are taken under a given condition $(\mathrm{Ma}=6, \mathrm{H}=25 \mathrm{~km})$.

\section{A. Baseline Waverider}

The baseline waverider is generated by GCBWRG [10], a software used to design waveriders based on arbitrary conic flow field. The baseline waverider's length is $2 \mathrm{~m}$. The top surface is treated as a freestream surface. Fig. 2 shows the pressure contour in different sections of the waverider when the angle of attack is 0 degree. The shock wave is along the leading edge and the high pressure is trapped blow the lower surface. Fig.2 shows the lift-to-drag ratio versus the angle of attack. With base drag, $\mathrm{L} / \mathrm{D}$ is 5.65 for $\mathrm{AoA}=0 \mathrm{deg}$, the maximum $\mathrm{L} / \mathrm{D}$ is 6.55 for $\mathrm{AoA}=2$ deg. The lift coefficient appears with the maximum L/D is 0.06235 (reference area is the projected area in $\mathrm{Z}$ direction). 


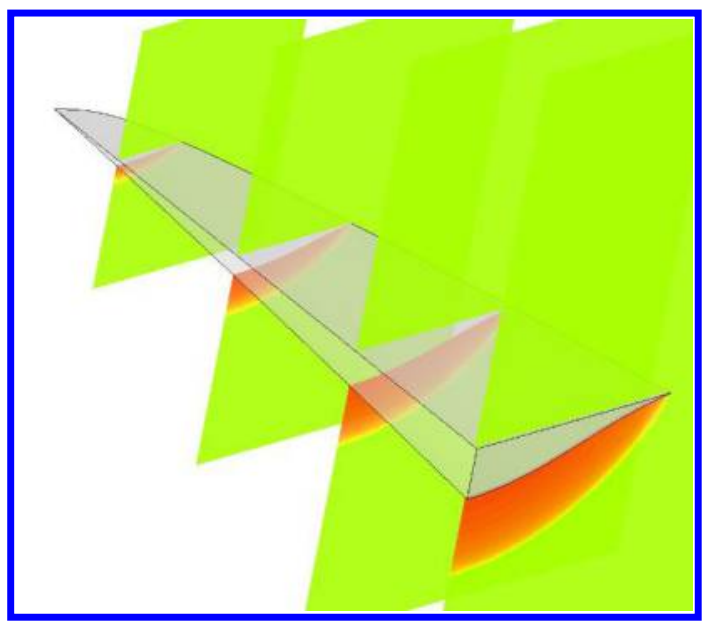

Figure 2. Baseline waverider (half model) and its pressure contours at different cross sections

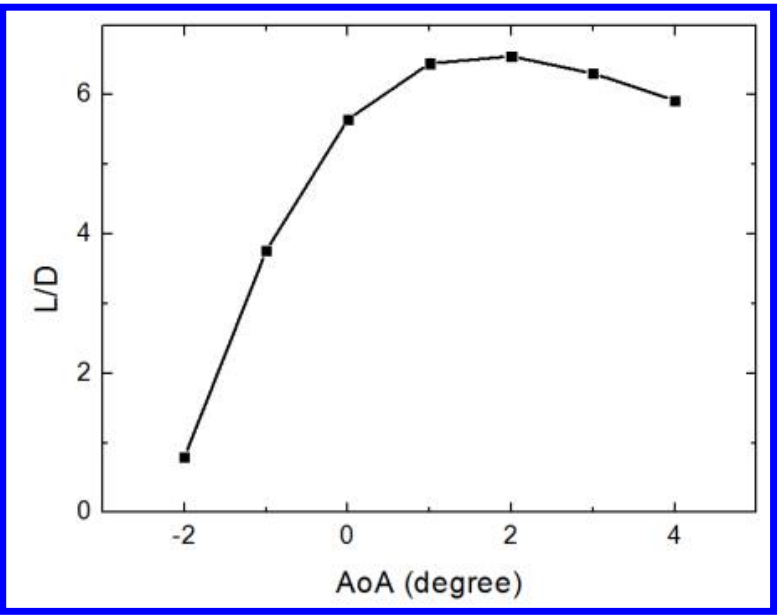

Figure 3. Variation of the lift-to-drag ratio values with flight angle of attack for baseline waverider

\section{B. Optimization Method}

The maximum $L / D$ is chosen as the optimization objective, with a constraint that the lift coefficient should not decrease. The optimization model is written as the following mathematical formulation:

$$
\begin{array}{ll}
\max & K(\mathbf{p}) \\
\text { s.t. } & C_{l}(\mathbf{p}) \geq 0.06235
\end{array}
$$

Where, $\boldsymbol{P}$ is the vector of design variables, objective function $\mathrm{K}$ is the $L / D, C_{l}$ is lift coefficient. By combining the objective function and constrains into a penalty function, this problem can be attacked by solving an unconstrained problem:

$$
\min _{\mathbf{p}} \quad J=\frac{K_{0}}{K(\mathbf{p})}+\lambda \cdot \max \left\{0, \frac{0.06235-C_{l}(\mathbf{p})}{C_{l}(\mathbf{p})}\right\}
$$

$K_{0}$ is the maximum $L / D$ of the baseline waverider, $\lambda$ is the penalty parameter which is set to be 100 here. There are 5 variables for the optimization, they are given in table.1. 
Table 1. Boundary values of design space

\begin{tabular}{ccc}
\hline Variable & Lower bound & Upper bound \\
\hline$H_{\max }(\mathrm{m})$ & -0.1 & 0.1 \\
$P_{1}$ & 0.2 & 0.9 \\
$P_{2}$ & 0.1 & 0.4 \\
$P_{3}$ & 0.5 & 0.8 \\
$\alpha($ degree $)$ & 0.1 & 6.0 \\
\hline
\end{tabular}

The differential evolution algorithm [30] is used as the optimization method, its process is shown in fig.4.

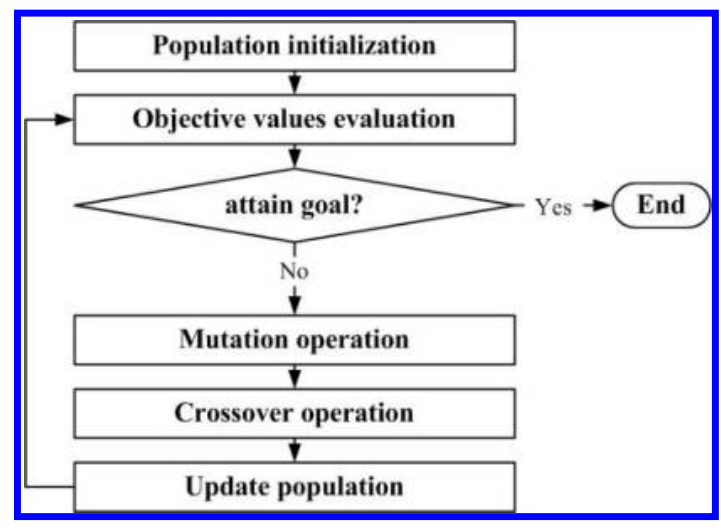

Figure 4. Flowchart of differential evolution algorithm

\section{Optimization Results and Analysis}

History of convergence of the L/D and the lift coefficient is shown in fig.5. After optimization, the maximum $\mathrm{L} / \mathrm{D}$ is 8.39 , there is an increment of 29.1 percent in comparison with the baseline configuration. Lift coefficient is 0.06248 , slightly higher than the baseline configuration $(0.2 \%)$. It can be seen that the L/D of the waverider can be significantly improved without decrease of lift coefficient after optimization. In addition, the maximum L/D in the whole process is $9.69,50 \%$ higher than the baseline waverider, however, its lift coefficient is only 0.04042 , which is out of constraint condition. It shows that lift constraint is a strong constraint.

In order to evaluate the validity of the waverider design method that based on the local shape deformation, two optimized configurations are selected out. One has the maximum deformation, the other has the minimum deformation. Their pressure contour at different cross-sections for $\mathrm{AoA}=0 \mathrm{deg}$ under the specified design condition are shown in fig.6. It is obviously different between the compression surfaces of the two waveriders. However, under the specific design condition, the shock wave is along the leading edge and the high pressure is trapped below the lower surface. Hence the waverider design method based on the local shape deformation works well. 


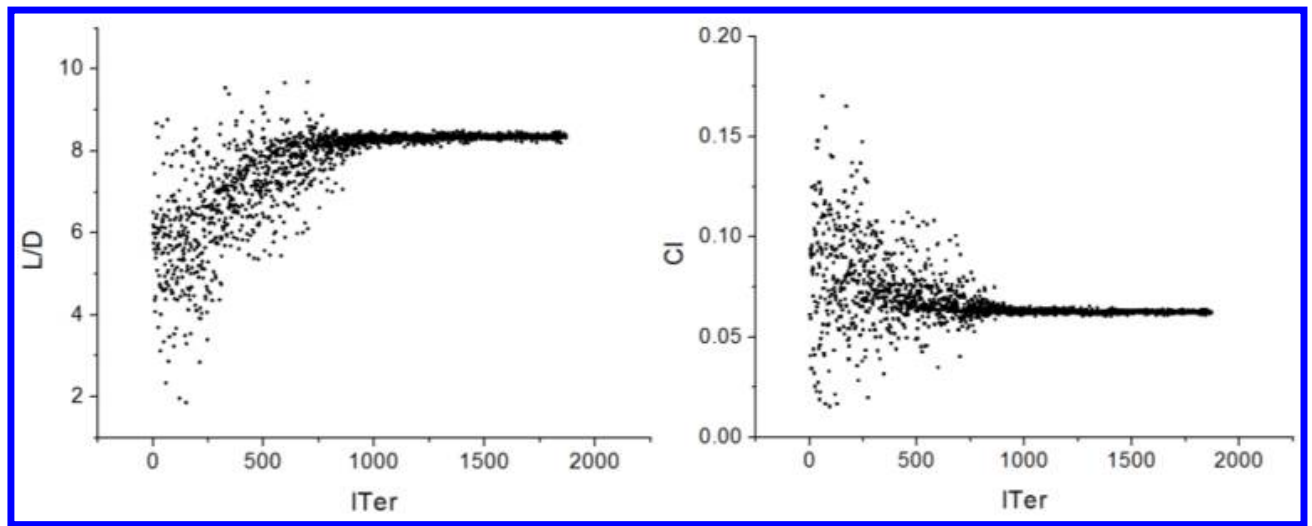

Figure 5. History of convergence of the $L / D$ (left) and the lift coefficient (right)

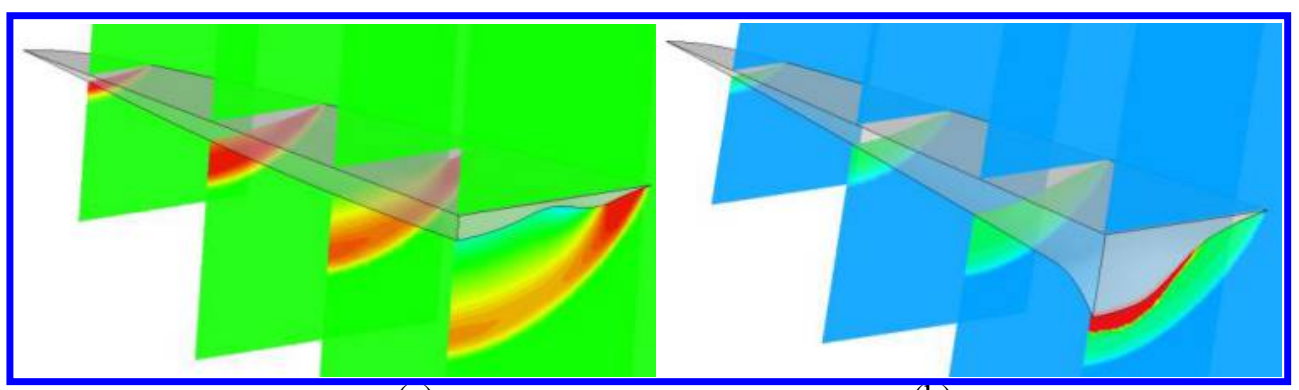

(a)

(b)

Figure 6. Pressure contours at different cross-sections of the two waveriders

Figure 7 shows the pressure isolines at the ending edge compared with the baseline waverider. For both groups, the left is baseline waverider, the right is the deformed waverider. As shown in the figure, the shock waves after deformation still match that before deformation. It confirms validity of the waverider design method.

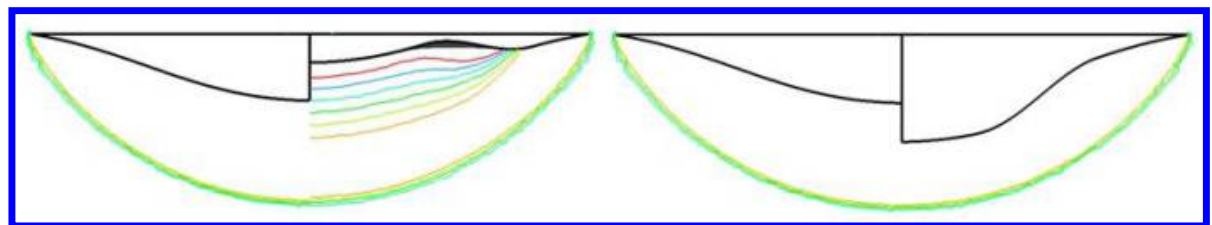

(a)

(b)

Figure 7. Pressure isolines comparison at the ending edge

Design variables and aerodynamic parameters of the two configurations are given in table 2 . We can see that changings of the compression surface would significantly affect the waverider's aerodynamic performance. The optimization space is greatly extended.

Table 2. Values of design variables and aerodynamic parameters of the two configurations

\begin{tabular}{ccc}
\hline & Configuration A & Configuration B \\
\hline$H_{\max }(\mathrm{m})$ & 0.1 & -0.1 \\
$P_{1}$ & 0.2 & 0.9 \\
$P_{2}$ & 0.4 & 0.2507 \\
$P_{3}$ & 0.8 & 0.6851 \\
$C_{l}$ & 0.01257 & 0.08625 \\
$C_{d}$ & 0.00201 & 0.05058 \\
$L / D$ & 6.25 & 1.71 \\
$X_{c p}$ & 0.43 & 0.90 \\
\hline
\end{tabular}




\section{Aerodynamic Performance Evaluation of Blunted Waveriders}

In order to evaluate the effect of blunted leading edge and viscosity, six configurations are selected out from the prior optimized results for further analysis. Figure 8 gives the 6 typical waverider configurations. They are all blunted with a diameter for $10 \mathrm{~mm}$ and calculated based on N-S equation.

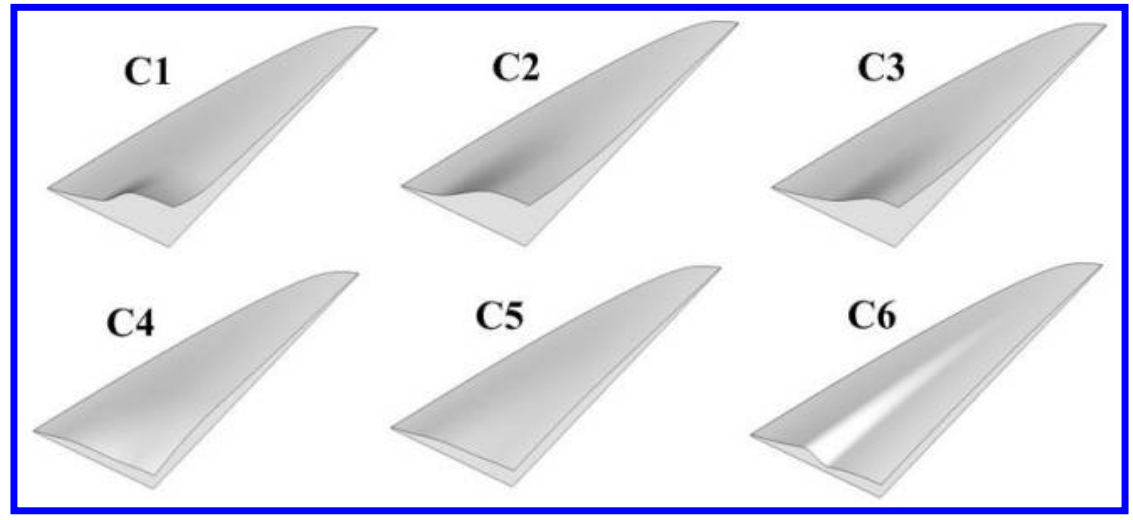

Figure 8. Shapes of typical waverider configurations

Multi-blocks structured mesh is used, and all cases are using the same parameters for comparison. The total grid number is about 2.32 million, meshes adjacent to the solid surface are compressed to fit the boundary layer, with the first layer for $0.2 \mathrm{~mm}$. The calculation is carried out with TVD scheme, implicit method and $k-\varepsilon$ model.

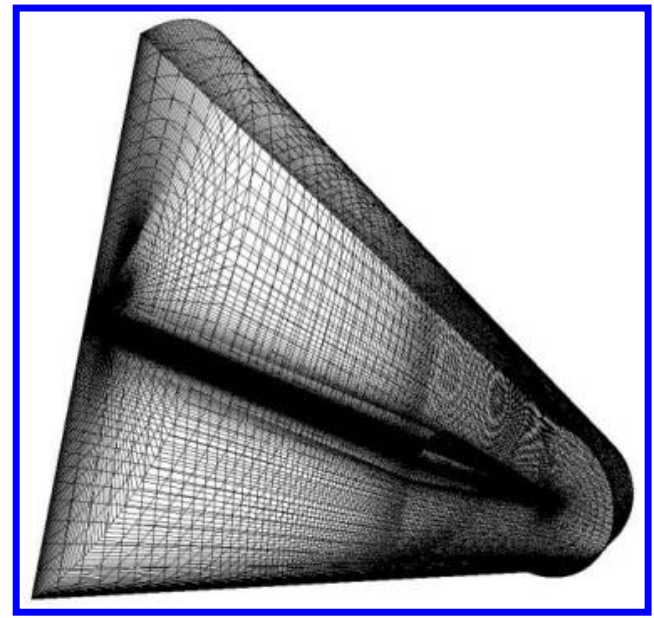

Figure 9. Grid structure for viscous analysis of blunt-edge waveriders

At the design condition ( $\mathrm{AoA}=5 \mathrm{deg}$ ), pressure contours at trailing edge plane of the 6 waveriders are given in figure 10 and compared with the baseline waverider. It shows that, when including the effect of blunted leading edge and viscosity, the shock wave is not strictly along the leading edge and the high pressure appears to leak. However, the shock wave's position, the pressure distribution adjacent to the shockwave and the top surface still match the baseline waverider. It confirms that, after local shape deformation of the compression surface, the waveriders' properties are kept. Hence, this design method can be used in the condition wherein blunted leading edge and viscous effect is included.

Table 3 shows the aerodynamic performance results. $C_{l}$ is lift coefficient, $C_{d}$ is drag coefficient, $\mathrm{L} / \mathrm{D}$ is the lift-todrag ratio, $X_{c p}$ is the relative coefficient of pressure center. $\mathrm{C} 0$ is the baseline waverider (with blunted leading edge when evaluating the viscous effect). C1-C6 are the 6 typical waverider configurations shown in figure 8. It shows that when blunted leading edge and viscous effect are included, $C_{l}$ has little difference but $C_{d}$ decreases significantly. The maximum L/D changes. However the changing trend is same in two conditions. From C1 to C6, L/D increases 
linearly in inviscid condition. When blunted leading edge and viscous effect are included, L/D still increases linearly. It means that one can take inviscid optimization firstly, then take viscous optimization with blunted leading edge based on previous result. Optimization efficiency can be greatly improved by this method. Moreover, L/D of C6 is twice as that of $\mathrm{C} 1$, it shows that aerodynamic performance can be greatly improved by means of compression surface optimization.

Figure 11 shows pressure contours on lower surfaces of the prior waveriders with different compression surfaces. It can be seen that, the pressure distribution of different shapes of compression surfaces differ from each other. It's the cause of aerodynamic performance changes. Difference of pressure distribution also caused the difference of pitch moment. Because of this, $X_{c p}$ is changed.

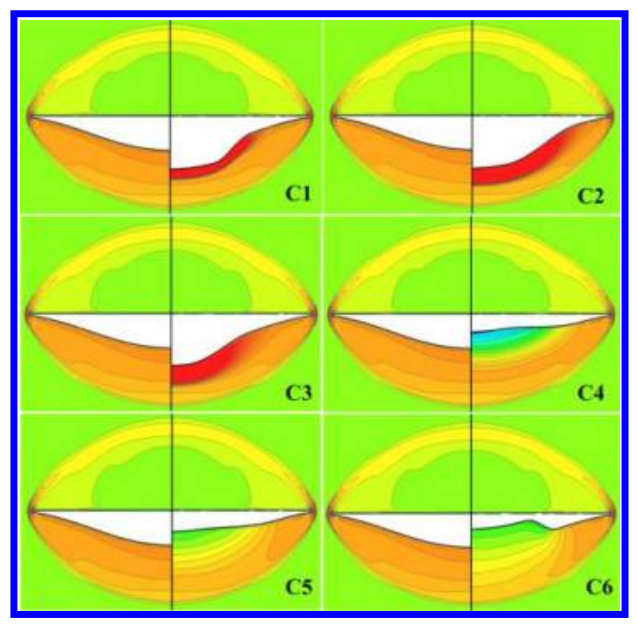

Figure 10. Pressure contours comparison at trailing edge plane of different waveriders

Table 3. Comparison of aerodynamic parameters based on different numerical models for typical waveriders

\begin{tabular}{ccccccccc}
\hline \multirow{2}{*}{ Configuration } & $\alpha$ & $\alpha(\mathrm{deg})$ & \multicolumn{5}{c}{ Euler } & \multicolumn{5}{c}{ N-S } \\
\cline { 3 - 9 } & & $C_{l}$ & $C_{d}$ & $L / D$ & $C_{l}$ & $C_{d}$ & $L / D$ & $X_{c p}$ \\
\hline C0 & 2 & 0.06235 & 0.00959 & 6.55 & 0.0608 & 0.0146 & 4.17 & 0.632 \\
C1 & 0.19 & 0.06911 & 0.02411 & 2.87 & 0.0679 & 0.0290 & 2.34 & 0.822 \\
C2 & 0.1 & 0.06073 & 0.01555 & 3.91 & 0.0593 & 0.0206 & 2.88 & 0.760 \\
C3 & 1.64 & 0.07328 & 0.01499 & 4.89 & 0.0724 & 0.0203 & 3.57 & 0.692 \\
C4 & 5.56 & 0.09693 & 0.01646 & 5.89 & 0.0985 & 0.0222 & 4.43 & 0.573 \\
C5 & 4.15 & 0.07760 & 0.01131 & 6.86 & 0.0784 & 0.0168 & 4.67 & 0.583 \\
C6 & 3.69 & 0.06419 & 0.00817 & 7.86 & 0.0648 & 0.0136 & 4.78 & 0.577 \\
\hline
\end{tabular}




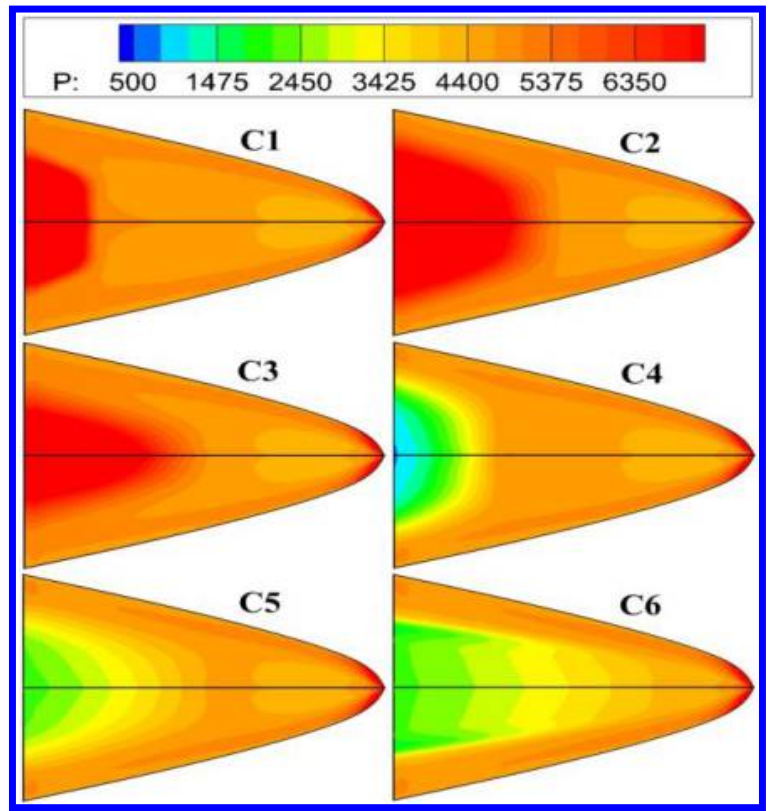

Figure 11. Pressure contours on lower surfaces of waveriders with different compression surfaces

\section{Conclusion}

In this paper, we developed a novel design method of waveriders which is based on a local shape deformation technique, and researched the effect of compression surface deformation on aerodynamic performances of waveriders by integrating numerical optimization and computational fluid dynamic analysis. The results confirm the validity of the waverider design method. Combining with the increment-based parameterization method, the compression surface can be changed in a big scope, with the configuration's "waverider" property kept. The numerical results show that, with leading edge held fixed, the optimization space of the lift coefficient, the drag coefficient and the pressure center is greatly extended.

\section{Acknowledgement}

This research was funded by the National Natural Science Foundation of China (NSFC) under grant numbers 11372324 and 11572333.

\section{References}

${ }^{1}$ Youda, Y., "Study on aerodynamic characteristic and design of optimization for high speed near space vehicles," Advances in Mechanics, Vol. 39, No. 6, 2009, pp. 683-694.

$\downarrow^{2}$ Ferguson, F., Dasque, N., Dhanasar, M., and Isaiah, M. B., "Waverider design and analysis," 20th AIAA International Space Planes and Hypersonic Systems and Technologies Conference, AIAA Paper 2015-3508, 2015.

$\checkmark{ }^{3}$ Lunan, D. A., "Waverider, a revised chronology," 20th AIAA International Space Planes and Hypersonic Systems and Technologies Conference, AIAA Paper 2015-3529, 2015.

${ }^{4}$ Ferguson, F., Dasque, N., Dhanasar, M. et al, "The design, analysis and performance evaluation of waverider configurations for hypersonic vehicle applications," 53rd AIAA Aerospace Sciences Meeting, AIAA Paper 2015-1008, 2015.

${ }^{5}$ Jones, J. G., Moore, K. C., Pike, J., et al, "A method for designing lifting configurations for high supersonic speeds, using axisymmetric flow fields," Ingenieur-Archiv, Vol. 37, 1968, pp. 56-72.

${ }^{6}$ Rasmussen, M. L., "Waverider configurations derived from inclined circular and elliptic cones," Journal of Spacecraft and Rockets, Vol. 17, No. 5, 1980, pp. 537-545.

7Doty, R. T., Rasmussen, M. L., “Approximation for hypersonic flow past an inclined cone,” AIAA Journal, Vol. 11, 1973, pp. 1310-1315.

${ }^{8}$ Rasmussen, M. L., Clement, L. W., "Cone-derived waveriders with longitudinal curvature," 11th Atmospheric Flight Mechanics Conference, Guidance, Navigation, and Control and Co-located Conferences, AIAA Paper 84-2100, 1984. 
${ }^{9}$ Takashima, N., Lewis, M. J., "Waverider configurations based on non-axisymmetric flow fields for engine-airframe integration," 32nd Aerospace Sciences Meeting and Exhibit, Aerospace Sciences Meetings, AIAA Paper 94-0380, 1994.

${ }^{10}$ Cui, K., Yang, G. W., "Waverider configurations derived from general conical flowfields," Acta Mechanica Sinica, Vol. 23, No. 3, 2007, pp. 247-255.

${ }^{11}$ Cui, K., Yang, G. W., "The effect of conical flowfields on the performance of waveriders at mach 6," Chinese science bulletin, Vol. 52, No. 1, 2007, pp. 51-64.

$\rightarrow{ }^{12}$ Ding, F., Liu, J., Chen, C. B. et al, "Novel approach for design of a waverider vehicle generated from axisymmetric supersonic flows past a pointed von Karman ogive,” Aerospace Science and Technology, Vol. 42, 2015, pp. 297-308.

${ }^{13}$ Zhenjun, L., Jiangfeng, W., Yizhao, W., et al, "Design and analysis of multistage compression cone-derived waverider configuration,” Journal of Astronautics, Vol. 36, No. 5, 2015, pp. 518-523.

${ }^{14}$ Steelant, J., Langener, T., Matteo, F. D. et al, "Conceptual design of the high-speed propelled experimental flight test vehicle HEXAFLY," 20th AIAA International Space Planes and Hypersonic Systems and Technologies Conference, AIAA Paper 2015-3539, 2015.

${ }^{15}$ Pezzella, G., Marini, M., Reimann, B., et al, “Aerodynamic design analysis of the HEXAFLY-INT hypersonic glider," 20th AIAA International Space Planes and Hypersonic Systems and Technologies Conference, AIAA Paper 2015-3644, 2015.

$\checkmark{ }^{16}$ Ding, F., Liu, J., Shen, C. B., et al, "Novel inlet-airframe integration methodology for hypersonic waverider vehicles," Acta Astronautica, Vol. 111, 2015, pp. 178-197.

${ }^{17}$ Liu, J., Ding, F., Huang, W., et al, "Novel approach for designing a hypersonic gliding-cruising dual waverider vehicle," Acta Astronautica, Vol. 102, 2014, pp. 81-88.

${ }^{18} \mathrm{Li}, \mathrm{Y}$. Q., An, P., Pan, C. J., et al, "Integration methodology for waverider-derived hypersonic inlet and vehicle forebody," 19th AIAA International Space Planes and Hypersonic Systems and Technologies Conference, AIAA Paper, 2014-3229, 2014.

${ }^{19}$ Cui, K., Hu, S. C., Li, G. L., et al, "Conceptual design and aerodynamic evaluation of hypersonic airplane with double flanking air inlets," Science China Technology Science, Vol. 56, No. 8, 2013, pp. 1980-1988.

${ }^{20} \mathrm{Hu}, \mathrm{S}$. C., Cui, K., Li, G. L., et al, "Optimization and analysis of the leading edge shape for hypersonic airplanes based on DoE methods," Chinese Journal of Theoretical and Applied Mechanics (submitted for publication).

${ }^{21}$ Bowcutt, K. G., Anderson, J. D., Capriotti, D., "Viscous Optimized Hypersonic Waveriders," 25th AIAA Aerospace Sciences Meeting, Aerospace Sciences Meetings, AIAA Paper 87-0272, 1987.

${ }^{22}$ Corda, S., Anderson, J. D., "Viscous Optimized Hypersonic Waveriders Designed from Axisymmertirc Flow Fields," 26th Aerospace Sciences Meeting, Aerospace Sciences Meetings, AIAA Paper 88-0396, 1988.

${ }^{23}$ Zhang, F. T., Cui, K., Yang, G. W., et al, "Optimization design of waverider based on the artificial neural networks," Chinese Journal of Theoretical and Applied Mechanics, Vol. 41, No. 3, 2009, pp. 418-424.

-24 Lobbia, M. A., Suzuki, K., "Experimental investigation of a Mach 3.5 waverider designed using computational fluid dynamics" AIAA Journal, Vol. 53, No. 6, 2015, pp. 1590-1601.

${ }^{25}$ Ryan, K. M., Lewis, M. J., Yu, K. H., "Comparison of robust optimization methods applied to hypersonic vehicle design," Journal of Aircraft, Vol. 52, No. 5, 2015, pp. 1510-1523.

${ }^{26}$ Lobbia, M. A., "Optimization of waverider-derived crew reentry vehicles using a rapid aerodynamics analysis approach," 53rd AIAA Aerospace Sciences Meeting, AIAA Paper 2015-0757, 2015.

${ }^{27}$ Lobbia, M. A., "Multidisciplinary design optimization of hypersonic transport configurations using waveriders," 19th AIAA International Space Planes and Hypersonic Systems and Technologies Conference, AIAA Paper 2014-2359, 2014.

${ }^{28}$ Bauer, SXS., "Analysis of Two Viscous Optimized Waveriders," Proceeding of the First International Hypersonic Waverider Symposium, 1990, Univ. of Maryland, College Park, MD, USA

${ }^{29}$ Charles, E. C., "Interpretation of waverider performance data using computational fluid dynamics," Journal of Aircraft, Vol. 31, No. 5, 1994, pp. 1095-1100.

${ }^{30}$ Stron, R., Price, K., "Differential evolution - a simple and efficient heuristic for global optimization over continuous spaces," Journal of Global Optimization, Vol. 11, 1997, pp. 341-359. 